\title{
ENGLISH-IGBO GLOSSARY CREATION OF PALM OIL PRODUCTION AND PROCESSING TERMS
}

\author{
Daniel I. Ilechukwu \& Aloysius U. Umeodinka \\ http://dx.doi.org/10.4314/og.v12i s1.11
}

\section{Abstract}

The Igbo speaking people are well known for palm oil production and processing in Nigeria. This occupation is one of the lucrative ventures among other trades or occupations for which the Igbo are known. With recent technological advancement in the method of production and processing palm oil, more English terms that do not exist in the lgbo language create communication problems. It is expected that the Igbo farmers of south-eastern Nigeria should be equipped with the Igbo equivalents of both the new and old terms involved in this venture for a balanced and free flow of communication. To achieve this objective, this paper comes to fill the gap of lack of an Igbo glossary for the technical terms involved in palm oil production and processing. The study is anchored on such translation techniques as Adaptation, Calque, Naturalisation, Transposition, Modulation and Loaning. It is a rendition from English to Igbo. Findings of the study indicate that some English terms have no Igbo equivalents, which calls for the documentation of terms in this area. Again, it finds out that some unschooled translators create terms indiscriminately without following the morphological rules involved in the process, thereby making it difficult to comprehend. Sequel to this, the paper discovers that readers of English-Igbo translated texts need to be cautioned not to take every product of translation with much seriousness. Based on these findings, the researcher recommends that the federal government should give the needed support for research development; translators involved in terminology should register with international organizations for unification of terminological neologism.

\section{Introduction}

Oil palm appears to be one of the cash crops that Nigeria cares for. Its multi-purpose use cannot be overemphasized. It serves as a source of revenue to a greater number of the rural population of 
the Igbo in particular and Nigeria in general.For the reason of its many advantages, oil production involves some technology. The activities like land preparation, field transplanting, fertilization, pest control and maintenance of the plantation are all responsibilities in the processing of palm oil. The activities involved right from the sprouting level in the nursery to the stage of crop harvesting in the field make up oil production technologies. All these activities call for language of expression. The items used are concepts and ideas in oil production and processing which the Igbo need to be conversant with.

Some modern techniques have been introduced in palm oil production and processing in the Igbo-speaking areas of the South Eastern Nigeria. The integrated pest control and management have not been recognized widely and this has been affecting yield negatively. Even the English foreign terms involved are unknown and strange to indigenous farmers. All these have impeded transaction and acquisition of the modern techniques. Besides, death has been gradually claiming the lives of most of the elderly palm oil production farmers, and the young ones are not eager to take after them. The absence of a language register can cause many problems when these elderly farmers are extinct.It is against this backdrop that this study is centred on An Igbo Glossary Creation for Palm Oil Production and Processing Terms. The study is charged with the goal of generating a list of often difficult or specialized words or expressions in palm oil production and processing, and giving them Igbo translations and/or definitions.

To accomplish this set target, the different techniques of translation will be called into use as and when necessary, in order to have the experience and attitudes of another culture or mentality of the modern technology in the Igbo language. In the first section, the introduction will be done, followed by the review of relevant literature in the second. The third section will address the research methodology. Data presentation and analysis will be done in section four, while the fifth section will take care of the summary of findings and conclusion. 
Ilechukwu \& Umeodinka: English-Igbo glossary creation of Palm oil...

\section{Literature Review}

Here we are going to look at some related literature to our topic of discussion.

\section{Theoretical Studies}

\section{The Concept of Translation}

The word translation is derived from the Latin word "translatio" meaning "to carry across,"House (2009:4) defines translation as "the process of replacing a text in one language by a text in another language". This means in essence, the restatement of the forms of one language in another: The Chief means of information between different language communities. There is the need to emphasize that speaking two or more languages does not qualify one as a translator, rather translation is an acquired skill of expressing a particular culture so that the message conveyed to the new audience remains unchanged. This skill is acquired over many years of practice after the individual has acquired the necessary basic language skills.

\section{Fidelity and Fluency}

Fidelity (or faithfulness) and fluency are two qualities that have been regarded as ideals to be striven for in translation, particularly 'literary translation.' 'Fidelity' pertains to the extent to which a translation accurately renders the meaning of the source text, without distorting it. 'Fluency' pertains to the extent to which a translation appears to a native speaker of the target language to have originally been written in that language, and conforms to the language's grammatical, syntactic and idiomatic conventions.

A competent translator must have the following qualities:

i. Must be familiar with the subject matter of the text being translated.

ii. A good knowledge of the language, written and spoken, from which he is translating

iii. Must have an excellent command of the language into which he is translating (the target anguage)

iv. A profound understanding of the etymological and idiomatic correlates between the two languages. 
v. A finely tuned sense of when to "metaphrases" ('translate literally') and when to "paraphrase" so as to assure true rather than spurious "equivalent" between the source and target language texts.

\section{Translation Techniques}

Ezeuko (1997) enumerates the seven special skills employed for the purpose of good translation as proposed by J. P. Vinary and J. Darbelnett, thus:

i. Loaning: This is seen as borrowing or lifting words from one language into another without the word being translated or modified. Loaning could involve expression and not words alone. One outstanding rule with Igbo is that the orthography and phonology of the language must be used in writing the word borrowed Ezeuko (1997).

Example:

\begin{tabular}{|l|c|}
\hline English & Igbo \\
\hline Ball & Bọol \\
\hline Engine & Njin \\
\hline Linguistics & Linguistik \\
\hline Astrology & Astrọloji \\
\hline Office & Ọfis \\
\hline
\end{tabular}

ii. Calque: This is the process of copying or initiating the structure of a foreign language term in coining an equivalent indigenous term.

Example:

\begin{tabular}{|l|l|}
\hline English & Igbo \\
\hline Happy Christmas & Hapi Krismasi \\
\hline Science-fiction & Sayens fikshọn \\
\hline
\end{tabular}

iii. Adaptation: This is the process of copying or borrowing a word in the indigenous orthography although the 
Ilechukwu \& Umeodinka: English-Igbo glossary creation of Palm oil...

sound may not correspond. Adaptation is close to naturalization.

Example:

\begin{tabular}{|l|l|}
\hline English & Igbo \\
\hline Linguistics & lingwistiiki \\
\hline Certificate & Safrikeeti \\
\hline Ball & Boolu \\
\hline Degree & Digrii \\
\hline Oxygen & Osijin \\
\hline Fridge & Firiiji \\
\hline
\end{tabular}

iv. Naturalization: This is the act of borrowing words and using the orthography of the target language (TL) in writing them according to the sound of the language. It is otherwise known as Igbonization.

Example:

\begin{tabular}{|l|l|}
\hline \multicolumn{1}{|c|}{ English } & Igbo \\
\hline Agriculture & Agrịọlchọ \\
\hline Astrology & Astrọlọji \\
\hline Astronomy & Astrọnọmi \\
\hline Geology & Jiọlọji \\
\hline Morphology & Mọfọlọji \\
\hline
\end{tabular}

v. Transposition: This involves two or more items changing position. It is a change in grammatical category.

Example:

\begin{tabular}{|l|l|}
\hline English & Igbo \\
\hline $\begin{array}{l}\text { He insisted on } \\
\text { immediate }\end{array}$ & $\begin{array}{l}\text { O siri onwụ ka a } \\
\text { kwụo ya ugwo ngwa } \\
\text { ngwa }\end{array}$ \\
\hline Men are $\underline{\text { insane }}$ & $\begin{array}{l}\text { Isi adighị ụmụ } \\
\text { nwoke mma }\end{array}$ \\
\hline
\end{tabular}

vi. Modulation: This is the act of changing the view point of the message. It can either be obligatory or 
optional. For instance, in Igbo, euphemism may be Example: used instead of writing the actual words/expressions.

\begin{tabular}{|l|l|}
\hline Igbo & Igbo \\
\hline O jere inyụnsi & O gara ịhu nwaanyị mụrụ nwa n'ọịa \\
\hline O na-awịara & isi adighị ya mma \\
\hline Ọ na-ezuohi & O na-eme aka ntụtụ \\
\hline
\end{tabular}

vii. Equivalence: Equivalence is depicting a relationship of equal value. It implies to idiomatic expressions, proverbs, etc. Here, you do not have the same style, but you have something that can or is similar in arriving at the same meaning.

\begin{tabular}{|l|l|}
\hline English & Igbo \\
\hline $\begin{array}{l}\text { If there is no cross there } \\
\text { be no crown }\end{array}$ & $\begin{array}{l}\text { Aka aja aja na-ebute ọụ } \\
\text { Mmanụ mman }\end{array}$ \\
\hline A stitch in time saves nine & E mee ngwan gwa e meghara ọdachi \\
\hline $\begin{array}{l}\text { Make hay while the sun } \\
\text { shines }\end{array}$ & Were ehihie chọwa ewu ojii \\
\hline $\begin{array}{l}\text { He who laughs last laughs } \\
\text { best }\end{array}$ & Anụ nwere ndidi na-añu mmiri ọma \\
\hline
\end{tabular}

\section{Necessity of Documentation}

Language documentation is a lasting multipurpose record of language. Certainly the major reason why the researcher has decided to engage with the idea of documenting the terms involved in palm oil production and processing in the Igbo language is to curb the threat of language extinction in this field. This documentation will equally serve the following purposes:

i. Creating lasting communication is seen as one major linguistic response to the challenge of the increased level of language endangerment observable in recent times. 
ii. It is necessary to record all communicative events in a given area for reference purposes and posterity.

iii. Having a glossary in this work would serve as a model to linguists, lexicographers, terminologists, language teachers, students and prospective translators.

iv. Finally, to retain the language of palm oil production and processing in Igbo language.

\section{Empirical Review}

Some researched works by some scholars are reviewed here. Some of these works include thesis and projects in the light of translation and terminology.

Ezeuko (1997) says that each trade or profession has its own vocabulary. Specialized language is used in specific areas of human endeavour. For example, a specialist in agriculture may use terms that are specific to the profession as not used by others. But what these experts do affect the lives of many ordinary people. How well can an outsider understand what the experts are talking about? The expert language concerns us as individuals insofar as we make use of the findings or inventions. Every trade, industry or scientific development has its own technical terms. Technical terms can easily confuse the outsider or non-initiated.

Quoting Collerino (1992), Ezeuko (1997) points out that "the study of the system of concept underlying a given field is followed by the attempt to link them to corresponding terms by means of definition". A term is a cognitive tool that enables one to understand a concept. From a logical point of view, terms behave like names that are like signs denoting objects of any kind or indicating concept. Terms are therefore names belonging to a well-structured system.

For the characteristics of a term, a term must be transparent, specific, give room for continuity and economy. A term is said to be transparent when it is clear of what is being said. If the definition does not make the concept clear, then the concept is wrong. So the term must be classified where it belongs.

A term is said to be specific where there is the ability to distinguish one concept from the other and indicate the limit of such term. But if definition does not limit concepts, then the 
concept is wrong. On economy, a term given to a concept must be short and not sentential for clarity. For continuity, a term should be open-ended for further creation of more terms.

Example 1:

"Ampi" which forms the root can take "cilin" or "cloxacillin" as suffix in pharmaceutical industry to get "Ampicilin" and "Ampicloxacillin" respectively.

In Igbo, "Ahịị" can combine with these words: "mfe", "nkwe", "njụ", "nha", "mburuna", "mgbagwo", "ajụjụ", and "nchọ" to form terms such as:

\begin{tabular}{|c|c|}
\hline Igbo & English \\
\hline Ahịimfe & Simple sentence \\
\hline Ahịinkwe & Positive sentence \\
\hline Ahịiṇjụ & Negative sentence \\
\hline Ahirinha & Compound sentence \\
\hline Ahịimburụna & Conditional sentence \\
\hline Ahịintimiwu & Conditional sentence \\
\hline Ahịrịmgbagwọ & Complex sentence \\
\hline Ahiriajuju & Interrogative sentence \\
\hline Ahịinchọ & Optative sentence \\
\hline Ahịienweoge & Timeless sentence \\
\hline Ahiriokpuru & Underlying sentence \\
\hline Ahịịide & Kernel sentence \\
\hline Ahịrịukwu & Complex sentence \\
\hline Ahịimputaraukwu & Ambiguous sentence \\
\hline Ahịinndajọ & Anomalous sentence \\
\hline Ahịrịhaukwu & $\begin{array}{l}\text { Compound complex } \\
\text { sentence }\end{array}$ \\
\hline Ahịrịkwụgba & Co-ordinate sentence \\
\hline Ahịrịnso & Finite sentence \\
\hline Ahiriisi & Matrix sentence \\
\hline Ahịiasọasọ & Non finite sentence \\
\hline Ahịrịnsoro & Serial sentence \\
\hline Ahịrịmyiemetu & Parallel \\
\hline
\end{tabular}


Supporting the above view, Rotistav (1985:85) in his words says:

Terms must be systematic that is to say distinctive with a terminology system, and adequately reflect the referent. They must be fixed by usage, their forms and meaning known and accepted by users. They should be nonambiguous when used in specialized texts; therefore polysemy, homonymy, and synonymy are to be avoided.

In the field of translation, the translator who deals with specialized text faces problems of translating or finding the equivalence of these source terms in the target language. A translator who has a thorough competence in the two working languages must choose the word with the right meaning and the right referent for the given context Ezeuko (1997).

\section{Data Presentation and Analysis}

\section{Unit Operations Terms of Palm Oil Production and Processing}

\begin{tabular}{|c|c|c|}
\hline & Usoro & Oru \\
\hline 1 & $\begin{array}{l}\text { Fruit fermentation } \\
\text { (MgbachaMkpụruakwụ) }\end{array}$ & $\begin{array}{l}\text { Igbucha ụzari dị n’ogbe } \\
\text { akwụ ka ọchịcha ya dị mfe } \\
\text { oso oso. }\end{array}$ \\
\hline 2 & $\begin{array}{l}\text { Bunch chopping } \\
\text { (MgbuchaOgbeakwu) }\end{array}$ & $\begin{array}{l}\text { Igbucha ogbeakwụ maka } \\
\text { onwunwo }\end{array}$ \\
\hline 3 & Fruit sorting (Inwoakwu) & $\begin{array}{l}\text { Inwo akwụ na ịhọ ndị dị } \\
\text { n’ụzari }\end{array}$ \\
\hline 4 & $\begin{array}{l}\text { Fruit Digestion } \\
\text { (Osisimkpụrụakwụ) }\end{array}$ & $\begin{array}{l}\text { Isi mkpuruakwu ka mmanụ } \\
\text { wee gbaa mgbe a na- } \\
\text { ahọchapu avụrịu na } \\
\text { mkpuruaki }\end{array}$ \\
\hline 5 & $\begin{array}{l}\text { Fruit Boiling } \\
\text { (NsikwaMkpuruakwu) }\end{array}$ & $\begin{array}{l}\text { Isi mkpuruakwu iji gbochie } \\
\text { mmiri uka di na ya imebi. }\end{array}$ \\
\hline 6 & $\begin{array}{l}\text { Mash pressing } \\
\text { (Mwupummiri) }\end{array}$ & $\begin{array}{l}\text { Iji ike si n'igwe wughapu } \\
\text { mmiri putara n'akwu n'ite }\end{array}$ \\
\hline
\end{tabular}


Ogirisi: a new journal of African studies vol 12s 2016

\begin{tabular}{|c|c|c|}
\hline & & nro \\
\hline 7 & $\begin{array}{l}\text { Oil purification } \\
\text { (Nsikọmmirinammanụ) }\end{array}$ & $\begin{array}{l}\text { Isi mmiri na mmanụ dịkọo } \\
\text { ọụ iji mee ka mmiri taa, ka } \\
\text { e wee gbakọ̣ mmanụ maka } \\
\text { osisi ikpeazụ }\end{array}$ \\
\hline 8 & $\begin{array}{l}\text { Fibre-nut separation } \\
\text { (NchọpụtaAki Abụo) }\end{array}$ & $\begin{array}{l}\text { Ipịcha avụrivụ ugboro abụo } \\
\text { iji nweta mmanu nke abụo. }\end{array}$ \\
\hline 9 & $\begin{array}{l}\text { Second pressing } \\
\text { (Mpichaputammanụugboro } \\
\text { abuo) }\end{array}$ & $\begin{array}{l}\text { Ip̣icha avụrịvụ ugboro abụọ } \\
\text { iji nweta mmanụ nke abụo }\end{array}$ \\
\hline 10 & Nut drying (NghakpọAkị) & $\begin{array}{l}\text { Ighakpo aki maka otiti ya ma } \\
\text { e mechaa }\end{array}$ \\
\hline
\end{tabular}

\section{Glossary of English to Igbo Palm Oil Terms}

\begin{tabular}{|l|l|}
\hline English (Source Language & Igbo (target language) \\
\hline Artisanal processing & iji aka apaputa mmanụ \\
\hline Acceptable quality & Mmanụ bụ kpoo \\
\hline Axe/matchet & anyụike/mmaoge/obejiri \\
\hline Boilers filled by fibre & $\begin{array}{l}\text { iteakwụ ji avụrịị akwụ esonye } \\
\text { okụ }\end{array}$ \\
\hline Bunch cutting & Igbutuo gbeakwụ \\
\hline Bruised fruit & Mkpưrụakwụ mgbụia \\
\hline Bunch stem & obi ogbeakwụ \\
\hline Chemical & Ọgẉ nchekwa mmanụ/kemikal \\
\hline Capital intensive & Iwe nnukwu ego \\
\hline Colour and flavor & Agba na isi ụtọ mmanụ \\
\hline Cooling & ịọba mmanụ \\
\hline Cargo & Ụgbọ mbusa mmanụ \\
\hline Crude palm oil & Mmanụ agwaghị agwa \\
\hline Domestic mark & Akara ngwaahịa \\
\hline Discolouration & Mmanụ achabeghi uhie \\
\hline Extraction & $\begin{array}{l}\text { ̣̣papụta mmanụ dị n’avụịụ̣ } \\
\text { akwụ }\end{array}$ \\
\hline Extraction rate & $\begin{array}{l}\text { Ka mmanụ a papụtara si } \\
\text { agbapụta }\end{array}$ \\
\hline Extensively & uju (mmanụ) \\
\hline Edible oil trade & azụmahịa mmanụ oriri \\
\hline
\end{tabular}


Ilechukwu \& Umeodinka: English-Igbo glossary creation of Palm oil...

\begin{tabular}{|c|c|}
\hline Exocarp & Ahụ mkụrụakwụ \\
\hline Exude oil & Gbaa mmanu/haa mmanu \\
\hline Factory/unit & Ụlọ nsụakwụ \\
\hline Fractionated & ndịche mmanu na agbidi \\
\hline Factory site & Ebe ụlọoru mpapụta mmanụ dị \\
\hline $\begin{array}{l}\text { Fractionated liquid } \\
\text { and solid phases }\end{array}$ & $\begin{array}{l}\text { Ikewaputa mmanụ n'ebe agbidi } \\
\text { dị }\end{array}$ \\
\hline Filtering & iza mmanụ \\
\hline Fruit formation & Akwu ifo ogbe \\
\hline Flavour & isi/ukpo mmanu \\
\hline Fresh ripe & Ogbeakwụ kachara ọụu \\
\hline Cooking & Osisi mkpụrụakwụ \\
\hline Fibre & avụrịụ akwụ \\
\hline Free fatty acid (FFA) & Agbidi ụka \\
\hline Grinding & mpichapụta (mmanụ) \\
\hline Gravity & $\begin{array}{l}\text { Mkpuruakwu tara aki iputa } \\
\text { mmanu }\end{array}$ \\
\hline To harvest & igbu (akwụ) \\
\hline Hydrolysis & Iji mmiri saputa mmanụ \\
\hline Oxidation & igbapu mmiri e ji paputa mmanu \\
\hline $\begin{array}{l}\text { Harvesting techniques and } \\
\text { handling effect }\end{array}$ & $\begin{array}{l}\text { Usoro igbutu ogbeakwu na } \\
\text { obubu ya }\end{array}$ \\
\hline $\begin{array}{l}\text { Harvesting, transporting } \\
\text { and handling }\end{array}$ & $\begin{array}{l}\text { mgbutu, mbula na mpaputa } \\
\text { mmanụ }\end{array}$ \\
\hline High yield & akwụ ịcha n'uju \\
\hline International standard & Keozuruụwa \\
\hline Installations & Mwube igweọrụ \\
\hline $\begin{array}{l}\text { International } \\
\text { Manufacturers }\end{array}$ & ndị mmepụta mmanụ ozuruụwa \\
\hline Kilogram & Kilogram \\
\hline Kernel (twin seeded) & aki (mkpi) \\
\hline Large scale plant & nkwụ a kụrụ ebe o buru ibu \\
\hline Laboratory & labọretri \\
\hline Liquid and solid phases & Mmanụ aki na avụrivu \\
\hline Liquid fraction & $\begin{array}{l}\text { Oke mmanu } \\
\text { mkpuruakwu }\end{array}$ \\
\hline Loading and unloading & Mburu na mbutu akwụ \\
\hline
\end{tabular}


Ogirisi: a new journal of African studies vol 12s 2016

\begin{tabular}{|c|c|}
\hline of bunches & \\
\hline Loose fruit & Akwụ nworo enwo \\
\hline Lipolytic enzymes & Mmiri ime akwụ \\
\hline Mashing the fruit & isụ mkpụrụakwụ \\
\hline Mechanized oil palm mills & Asumakwụ ogbara ọụu \\
\hline Mechanization & Iji igwe paa mmanụ \\
\hline Mechanized processing & $\begin{array}{l}\text { Mpapụta mmanụ n'ụzọ oggbara } \\
\text { ohụu }\end{array}$ \\
\hline Mashing & osụsụ (akwụ) \\
\hline Mechanize handling & Iji igwe mpaputa mmanu \\
\hline Mill & Ụlọ mpapụta mmanu \\
\hline Mashing of pounding stage & isụ akwụ ghere eghe \\
\hline Mesocarp weight & Ihe avụrivu akwu dara \\
\hline Oil palm bunch & Ogbeakwụ \\
\hline Oil seed (such as groundnuts) & Mkpụruakwụ \\
\hline Oil winning process & $\begin{array}{l}\text { Usoro okachamma } \text { e } \\
\text { apammanu }\end{array}$ \\
\hline Oil seed explorer & Ude \\
\hline Oil content & $\begin{array}{l}\text { Ihe mmanụ na- nye n'ahụ/ihe } \\
\text { mmanụ dị n'ime ya }\end{array}$ \\
\hline Processing & ịsụchapụta (mmanụ) \\
\hline Plantations & Abọnkwụ \\
\hline Palm oil & Mmanụ akwụ \\
\hline $\begin{array}{l}\text { Processing out the } \\
\text { Crude palm oil }\end{array}$ & ipapụta mmanụ akwụ \\
\hline Purify and dry & $\begin{array}{llll}\begin{array}{l}\text { Zapụta mmanụ } \\
\text { avụrịụ }\end{array} & & & \text { gbakọ̣ } \\
\end{array}$ \\
\hline Processing operation & oru ipịchaputa mmanụ aki \\
\hline Post-harvest transport & Obubu ogbeakwụ \\
\hline Palm & Nkwụ \\
\hline Palm branch & Igunkwụ \\
\hline Palm chaff & ahịinha \\
\hline Palm fibre & avụrịvụ \\
\hline Palm frond (tender) & Ọmụ \\
\hline Palm husks & aghịigha/avụrịvụ \\
\hline Palm kernel & mkpưrụaki \\
\hline Palm nut & Mkpụruakwụ \\
\hline
\end{tabular}


Ilechukwu \& Umeodinka: English-Igbo glossary creation of Palm oil...

\begin{tabular}{|c|c|}
\hline Palm nut (with soft core) & Osukwu \\
\hline Palm tree diseases & Uhiama \\
\hline Palm nut & Mkpụrụakwụ \\
\hline Purifying & izachapu (mmanu) \\
\hline Pruning palm fronds & Igbuchanata omunkwu \\
\hline Refining & Isichapụta kpoo dị na mmanụ \\
\hline Refining industry & $\begin{array}{l}\text { Ụlọorụ na-esichapụta kpoo dị na } \\
\text { mmanụ }\end{array}$ \\
\hline Range & agbata/oke mmanụ e nwetara \\
\hline Research bodies & Out nchọpụta (maka mmanụ) \\
\hline Refined oil & kpoo dị na mmanụ \\
\hline Sterilizing & Isigbu nje (mmanụ) \\
\hline Super heated steam & $\begin{array}{l}\text { Onụ akwụ rere ere a machusiri } \\
\text { ike }\end{array}$ \\
\hline Sampling & itatụru mkpựụakwụ \\
\hline Supplying & Ibusa mmanu n'ahịa \\
\hline Small scale & ịpapụta mmanụ obere obere \\
\hline Spikeletes & Aghangu \\
\hline Stem & Okporo nkwụ/ogwe nkwụ \\
\hline Small scale processor & Igwe obere mpaputa (mmanu) \\
\hline Sterilization of bunches & Osisi ogbeakwụ \\
\hline Shell & Ichere \\
\hline Sedimentation & $\begin{array}{l}\text { Mmanụ nrọchikọ/eketeke/mmanụ } \\
\text { agbidi }\end{array}$ \\
\hline Soft exocarp & yọrịyọị avụrivụ \\
\hline $\begin{array}{l}\text { Traditional manual } \\
\text { procedure }\end{array}$ & Ụzọ ọdịnala e si emepụta mmanụ \\
\hline $\begin{array}{l}\text { Tedium and } \\
\text { drudgery }\end{array}$ & $\begin{array}{l}\text { Mmepụta mmanụ ịta akpụ/ahụhụ } \\
\text { dị na }\end{array}$ \\
\hline Trucks & Nnukwu uggbọala mbuakwụ \\
\hline Thermo-mechanical & Iji igwe chọpụta akwụ rebiri ọnụ \\
\hline To extract & ịuchaputa mmanụ dị n'akwụ \\
\hline Threshing & Inwo mkpưrụakwụ \\
\hline
\end{tabular}


Ogirisi: a new journal of African studies vol 12s 2016

\begin{tabular}{|c|c|c|}
\hline 1. & Black giants ants & Agbụsi igwe \\
\hline 2. & Caterpillar (larva form) & ọvụvụu/ọuguọo \\
\hline 3. & Domestic birds & Nnunu ulọ \\
\hline 4. & Ear wing & Ofevụu \\
\hline 5. & Grass cutter & Nchi \\
\hline 6. & Khaki weed (parasitic plant) & ahịhịa edo/ovuegbe \\
\hline 7. & Land crustacean pill bug & oti \\
\hline 8. & Maggot (larva form) & Ikpuru \\
\hline 9. & Mealy bug & Ụtụ akwụ \\
\hline 10. & Scarab beetle larva & Akpa nkwụ \\
\hline
\end{tabular}

Technique Application

SL (English)

TL (Igbo)

Harvesting Technique Usoro Nka Di N'Igbutu Akwu

"Harvesting technique" here is translated into the target language (Igbo) as "usoro nka di n'igbu akwụ". In Igbo, harvesting is understood as "owuwe ihe ubi" but in relation to harvesting of "palm bunch" in Igbo, it is realized as "igbu akwụ" while "technique" is realized in Igbo as "usoro nka". Equivalent technique is employed here.

\section{SL (English)}

Treshing

Literally the term "treshing" denotes "ikucha" or "iti cha ihe" in the target language (Igbo), but onwunwo mkpuruakwụ" is rather used for this expression in Igbo. The technique employed here is intra linguistic borrowing. (borrowed from the dialect of Achina Igbo).

\section{SL (English)}

Sterilization of bunches

"Sterilization of bunches" is given "osisi ogbeakwu" here in the target language (Igbo). Literally, "sterilization" means "nsicha" or "nsigbu" in the target language while "bunch" means "ogbeakwu" which is the equivalent. But to be in congruent with palm oil production and processing terms, is called "osisi" hence "osisi ogbeakwụ" for "sterilization of bunch". 
SL (English)

Digestion of the fruit
TL (Igbo)

Osusu Mkpuruakwu

"Digestion of the fruit" here is translated into the target language (Igbo) as "osụsu mkpuruakwu". In the target language (Igbo), digestion is seen as "ngweri" while "mkpuruakwu" is the equivalence of the "fruit". Since "digestion" connotes "pounding" in palm oil production and processing terms, it is realized as osusu. The technique employed is "modulation" owing to the significant change in the view point of the term "digestion".

\section{SL (English)}

Pressing

(mmanu)
TL (Igbo)

Mpaputa/ipa

Here, "pressing" in the source language (English) which denotes "opipi"in the target language has certainly changed to "ipa" (mmanu) in order to give its meaning in palm oil production and processing. Technique used here is equivalence.

\section{SL (English)}

TL (Igbo)

Domestic Mark

\section{Akara Ngwaahia}

"Domestic" in the source language here simply denotes "keihe/ejiri mara ihe" in the target language (Igbo). With regards to palm oil production and processing, domestic has been termed "ngwaahia", as a result of change of view point, while "mark" has been "akara ngwaahia" as its translation. The technique employed is equivalence and transposition due to a change in the position of terms that make both the source language (English) and target language (Igbo).

SL (English)

Oil Storage

"Oil storage" in the source language (English) has its equivalent

in the target language (Igbo) as "nchekwa mmanụ". Equivalent technique applies here.

SL (English)

Bunch chopping
TL (Igbo)

Nchekwa Mmanu

TL (Igbo)

Igbucha Ogbeakwu Maka Onwunwo 
"Bunch chopping" here is translated into the target language (Igbo) as "igbucha ogbeakwụ". In the target language (Igbo), chopping is being regarded as "ibe/obube" but in relation to palm oil production and processing. "chopping", is translated as "igbucha" while "bunch" has been given its equivalent. “Ogbeakwụ”.Hence, "igbucha ogbeakwụ”. Techniques employed are both equivalence and tansposition (view point is changed).

\section{SL (English)}

TL (Igbo)

Extracting the palm oil Ipaputa Mmanu Di na Mkpuruakwu The term "extracting" in the English context is rendered into Igbo as "ipaputa". We decided to accept "ipaputa" instead of "iweputa" which is inappropriate in the context in question. The techniques employed is equivalence.

\section{SL (English)}

Fractionated

TL (Igbo)

There is dilution in Igbo in the course of translating the source language (English) into Igbo. The source language "fractionate" which is only one term is translated into the Igbo language with up to four words thus, "ndịiche mmanu na agbidi".

\section{SL (English)}

TL (Igbo)

Clarification and drying

Oziza na Nchekpo

"Clarification and dry" here has been translated into the target language (Igbo) as "oziza na nchekpọ". In the target language (Igbo) clarification is literally assumed to mean "nkowada", while "dry" is understood as "mgbakpọghakpo" respectively. But in relation to preservation of palm oil, it is rendered as "oziza na nchekpọ" in the target language (Igbo). The technique employed is equivalence.

\section{SL (English)}

Percent

\section{TL (Igbo)}

"Percent" which is the source language (English), has been lifted into the target language (Igbo) to read "pasent" without any 
Ilechukwu \& Umeodinka: English-Igbo glossary creation of Palm oil...

further translation. The technique employed is calque which is also a type of loaning.

SL (English)

Liquid and solid phases

TL (Igbo)

Liquid literally means "Kemmiri" in the target language (Igbo) while solid is "keokpurukpu". To suit the domain of the research, the expectedequivalent, "liquid" has been realized as "mmanu" whereas "solid" has been given "aki/avurivụ". Modulation technique is observed following the significant change in the view point of the concepts involved.

\section{SL (English)}

Chemical

TL (Igbo)

"Chemical" which is the source language (English) is here adapted into the target language (Igbo) as "kemikalu". We do not have sound to sound correspondence in the SL and TL of the affected terms. So the technique is adaptation.

\section{SL (English)}

Installation

The term "installation" is diluted into three words "mwubeigweoru" in the target language (Igbo). The technique involved here is dilution.

\section{SL (English)}

Mechanized processing

Mechanized processing is translated into the target language (Igbo) as "ipa mmanu ogbara ohưự". In Igbo, "mechanized" denotes ijiigwerụoorự", while "processing" implies "nrụchapụta" respectively. In order to get the suitable term, "mechanized processing," is rendered as "ịpa mmanụ ogbara ọụrụ." Equivalent technique is employed.

\section{Summary of Findings}

The study has realised its objective of establishing an Igbo Glossary of Oil Production and Processing Terms. The following 
previously non-existing terms have been added to the Igbo word stock through this research: Harvesting technique is Usoro Nka Di N'Igbutu Akwu, Treshing is Onwunwo mkpuruakwu, sterilization of bunches is termed Osisi Ogbe akwu, Digestion of the fruit is Osusu mkpuruakwu, Pressing has the Igbo term Mpaputa/Ipa mmanu, Oil storage is Nchekwa mmanu, Bunch chopping is Igbucha ogbeakwu maka onwunwo, Classification and Drying is Oziza na Nchekpo, Percent is loaned to be pasenti and Mechanized processing is Ipa mmanu ogbaraohuru, to mention but a few.

Also established is that some terms are improperly created by some unschooled translators without abiding by the professional methods. We have also discovered that some terms like percent and laboratory do not have Igbo equivalents and so have to be inevitably loaned; others have to be coined, adapted and borrowed to avoid creating a vacuum.

\section{Conclusion}

The objective of this research has been to develop an EnglishIgbo Glossary for Oil Production and Processing Terms. This objective has been met as evidenced by the new terms generated and explained above. It is now clear that the palm oil production and processing word stock in Igbo does not remain the same, hence the farmers will now have a good flow of communication in their busines transaction. Even the mass media can now boast of new Igbo palm oil related terms which could be used for news casting in Igbo, etc.

\section{Suggestions and Recommendations}

Creating indigenous terms in any discipline is not an easy task. This paper has shown that Igbo language is endowed with mechanism for coining and inventing new words using various methods.

To further develop the Igbo language in the area of terminology, all the available methods and principles should be put to use. We need not fear to borrow from other languages to create new terms. Supporting this view is Yannani (1987:90) who points out that English which is one of the greatest languages of the world has about $50 \%$ of its vocabulary borrowed. It borrows 
Ilechukwu \& Umeodinka: English-Igbo glossary creation of Palm oil...

from French, Latin, and Greek. These borrowings have been made possible through translation. If the Hebrew language which was dormant for almost 2,000 years was revived, the Igbo language which is still on its developmental stage can go further especially in this area of creation and translation of terms.

In the light of research and findings, we recommend that:

1. The federal government should give the needed support for research development,i.e research in Nigerian language should be given the proper attention it deserves.

2. Research institutes should be well funded to enable them achieve their desired goal.

3. Translators involved in terminology development should register with international organizations for unification of terminological neologism/

4. Individual efforts in this area should be commended for the efforts towards term creation.

5. The mass media - the television and radio, the journals and newspapers should help in making newly created terms popular.

6. Professionals - teachers, lawyers, writers, journalists and general public should use such terms in their daily communication as they apply. 


\section{References}

Anyaehie, E. O. (1997). Studies in Terminology (Ed.) Okigwe: Fasmen Communications.

Catfford, J. C. (1974). Linguistic Theory of Translation. London: Oxford University Press.

Collerino, S. (1992).Considerations of General theory of Terminology in the Interpreters Newsletter No. 4.

Ezeuko, R. (1997). Steps to Process for High Quality Rice Grains.M.A.Thesis, Abia State University, Uturu.

Ezinwoke, S. O. (2004). Tropical Field Crops.Owerri: Evans Books.

Genty, P. R. (1978).Oil Palm Pests in Latin America. London: Chapman and Hall.

Hardter, R., Woo, Y. C. \& Obi, S. H. (1997). Intensive Plantation Cropping. London: Longman.

Hartley, C. W. S. (1988). The Oil Palm Tropical Agricultural Series. London: Longman.

House, J. (2009). Translation. New York: Oxford University Press.

Juan, P. V. (2005). Translation Theory.New York: Cornel University Press.

Kwasi, P. (2002). Small Scale Oil Processing in Africa.Retrieved from http://www.FAO.com on 30th August.

Labov, W. (1972).Language in the Inner City: Studies in the Black English Vernacular. Philadelphia: University of Pennsylvania Press.

Lecercle, J. J. (1990). The Violence of Language. London \& New York: Routledge.

Levenston, E. (1996). Towards a Comparative Stylistics.Journal of American English Teacher. Xv, 2:94-98.

Malone, J. (1988). The Science of Linguistics in Art of Translation. Albany: State University of New York Press.

Mannion, A. M. (1998). Agricultural and Environmental Charges. England: John Wiley and Sons.

Nkwenti-Aze, B. (1995).Translation Performance, Transaltion process and Translation Strategies. Tubinge:Narr. 
Ilechukwu \& Umeodinka: English-Igbo glossary creation of Palm oil...

Okeke, J. (1995). Translation of English-Igbo and Language Engineering in the Electronic Media. Benin: Barloz Publishers Inc.

Okolo, D.A. (2004). National Tree Crop Development Unit. Owerri; Evans Printing.

Ray, A. (1997). La Terminology non et notion. France: Press, University de France

Ronand, C. (1981). The Biology and Evolution of Language Masschusetts: Harvard University Press

Rostiv, J.C. (1994). Terminology and language. London: Oxford University Press.

Sager, J.C. (1994). Language Engineering and Translation:

Consequences of Automation. Amsterdam: Benjamins.

Turner, I. \& Emden, A. (1960). Oil Palm Pests in Latin America. London: Chapman and Hall.

Yannani, L. (1987). Answer to Qestions on Discussion on International Experience. London:

Edward Arnoid. 